\title{
A never-ending story
}

The gendered art museum revisited

Christensen, Hans Dam

Published in:

Museum Management and Curatorship

DOI:

10.1080/09647775.2015.1120682

Publication date:

2016

Document version

Peer reviewed version

Citation for published version (APA):

Christensen, H. D. (2016). A never-ending story: The gendered art museum revisited. Museum Management and Curatorship, 31(4), 349-368. https://doi.org/10.1080/09647775.2015.1120682 


\section{A never-ending story: the gendered art museum revisited}

\section{Introduction}

For many years the unequal acquisition of artworks by female artists compared to male artists has been a recurrent issue both within and outside the Danish art museum world. For example, in the year 2003 the Danish Minister of Culture had to reply to a question, submitted in the Parliamentary Chamber, about the acquisition policy of seven large art museums; the question addressed acquisitions in the period 1983-2003 in terms of gender, artists' age and price. The written reply resulted in the ministerial report Redeg $\phi$ relse for indkøbspolitikken 1983-2003 på syv danske kunstmuseer (Report on the Acquisition Policy at Seven Danish Art Museums 1983-2003, 2005). By way of comprehensive statistic material, which demanded quite an effort from the museums involved, this report documented that 80 $\%$ of the artworks by living artists acquired in the period were produced by male artists; in terms of deceased artists, $95 \%$ were by male artists.

Gender inequity in the art museum world is not a particularly Danish issue. To mention a very spectacular phenomenon often referred to in the debate, the art collective Guerilla Girls has aimed at the question in an abundance of ways since 1985. In scholarly as well as popular debates the question has also been raised repetitively. A seminal article is Linda Nochlin's “Why Have There Been No Great Women Artists?" (1971) which touched upon the issue in art history in general. In a publication channel rather distanced from this text, the Chicagobased trend culture magazine, $C U S P$, conducted its own unscholarly analysis of the displays of American and contemporary modern artists in the galleries of the Art Institute of Chicago during the summer of 2014; respectively $81 \%$ and $89 \%$ of the displayed artists were male (Cruz 2014).

Returning to Scandinavia, the comprehensive Swedish report, Representation och regionalitet. Genusstrukturer i fyre svenske konstmuseisamlingar (Representation and Regionality. Gender Structures in the Collections of Four Swedish Art Museums, Tellgren and Werner 2011), is also worth mentioning. In, for example, the internationally oriented Moderna Museet in Stockholm (opened in 1958 as an independent collection, separated from Nationalmuseum, the Swedish National Gallery of Art), female artists represented $16 \%$ of the total number of artists in the collection just a few years ago (Sundberg 2011). These are just a few cases in the almost infinite number of indices on the issue of imparity in art museums. 
Apparently, the art museum is an easy target with regard to gender as the issue is negotiated continually in the use of artists' names in acquisitions, collections, displays and exhibitions. The leading principles in knowledge organization of the art and art history domains are founded on the use of the artist's name, typically an evident denominator in terms of gender. In a wider perspective including cultural history museums, natural history museums and science centers, the question of equal status and opportunities is, however, repeated, though in different disguises.

For example, a variant, the "women's museum", surfaced at the end of 1970s in order to frame the cultural history of women which did not sufficiently appear in the traditional cultural museums. The gender issue is a little more complex in regard to natural history museums and science centers, but studies show, for example, how androcentric biases are present in the displays of male and female specimens. Without further explanations, the firstmentioned tends to dominate with respect to number, postures and positions repeating human gender schemes although this is not always the case in the animal worlds; male specimens also seem to dominate in quantity as well as in the style of language used in interpretative texts (Machin 2008). Other studies point out gender differences in parents' informal teaching of boys and girls in science museums which, again, echoes and reproduces accustomed gender stereotypes (Crowley 2000; Crowley et al. 2001).

In the art museum context, which will be prominent in the following, the quarrel of gender parity in acquisition, collection and display is too simplistic. Despite Guerilla Girls, theoretical aspirations, and the fact that explicit feminist theory and art have been present in the art world and the domain of art history since the 1970s (see, e.g., Dimitrakaki and Perry 2013), museum practices and discourses still seem to generate, or mirror, a gender inequity which seems out of line in comparison with, at least, the societal concern for gender mainstreaming in most Western societies in general. As the following will show, the quest for parity (and, implicitly, binarity) in acquisition of works of male and female artists overshadows important theoretical concerns on gender which parity might even contradict. Occasionally, critical reflections of this sort have surfaced in museum discourses during the last four decades, for example Hein's “conceptual restructuration” (2007). However, not least the simplifying opposition of male and female as biological sexes is a theoretical implication worth noticing. Queer museum studies promote a more flexible understanding of sex, gender and diversity in general, which is not allowed by the reductionist dichotomy of "man" and “woman" (see, e.g., Morrissey 2008; Steorn 2010). In a broader light these queer studies 
derive from feminist and gender studies following lines of ciritical thoughts that, among others, problematize "naturalized" concepts and categories; are against essentialistic definitions of identity suggesting that attributions are permanent and stabile; and always bring critical attention to the dominance of heterosexual norms (heteronormativity) as regulating social relationships in general (see, e.g. Haraway 1988; Degele 2008; Jackson 2006).

Firstly, this article returns to the handful of museums in the above-mentioned Danish ministerial report in order to review any changes in terms of gender equality. The article is not trying to compete with the scope of the report's comprehensive statistics. On the contrary, it is going to look for the devil in the details, that is, accessible information on the museum websites about new acquisitions and exhibitions, as well as presentations of contemporary art in the collections, that is, aspects which are interpreted as aggregates in composite discourses on gender. This is just a very small study, but with a more facetted approach the article indicates that the plain conclusions have not changed considerably since 2004 when the ministerial study was conducted, at least not if the results are indicative for the overall activities of the seven museums. Apparently, an imbalance, heavily weighted in favor of works by male artists, is still present. This is in contrast to the balance between male and female artists within, for example, the artists' associations in Denmark, and with regard to the awarding of artistic merits by the Akademiraadet (the Academy Council), a section of the Danish Royal Academy of Fine Arts (Akademiraadet 2014).

As has already been revealed in former research and reports, gender issues in museums might also be apparent in internal practices, that is, the museum as workplace, preferred job choices in the art museum, the number of directorships, and salary differences (Gan et al. 2014). Thus, the article next touches upon the issues of internal museum practices by examining the question of directorships at Danish art museums, both present and historically, in order to confirm a familiar pattern. A majority of female directors are also a well-known phenomenon in Denmark, and the unequal acquisition and exhibition policy cannot be reduced to a matter of an old boys' network. The gender imbalance, however, becomes a little more complex when the responsibility for learning activities in art museums is investigated. In a Danish context female experts heavily dominate this field and international comments indicate that this is not an unknown phenomenon elsewhere either.

Thirdly and last, the article discusses implications of these statistics from a theoretical perspective. Quantitative data might make social structures of everyday observable, but they 
are reducing complex social practices, and they are not divided from interpretative approaches (see e.g. Latour 2009; Mair, Greiffenhagen and Sharrock 2015). For example, having women as the majority of female museum workers and practising artists is not guaranteeing gender equity, and why should this be the case? More concern might perhaps arise in terms of female dominance within learning activities, notably, because it echoes a mythological relationship between the male artist and his muse. This might be a misreading, but apparently more in-depth analyses are needed in order to map the complex inequityproducing mechanisms. Critical analyses could, for example, address the concepts of art and value. On the one hand, the usage of "art value" can easily be criticized as a Teflon word, that is, a non-stick coating for art directors justifying their acquisition policy, and, moreover, a term that male and female artists often prioritize at the expense of gender. On the other hand, "art value" is not the smoking gun as directors, museum boards, etc., have made a series of strategic choices before "art value" becomes an issue at all.

In the long run, gender inequity in art museums could be dissolved by way of declared parity in, for example, acquisition policy, but this article is not arguing that this is the best solution, foremost because it overshadows gender-producing mechanisms in discourses and practices within as well as outside the art museum. Instead, lack of parity should be considered a symptom of something in need of investigation, a point of attention, which might have reasonable explanations, but, nevertheless, can also be addressed by gender mainstreaming, for example as it was adopted in Resolution 4 at ICOM's 28th General Assembly (2013):

\footnotetext{
We recommend that museums analyse the narratives being told from a gender perspective. / In order to have a gender policy, we recommend that museums work with audience, staff and programmes from a gender perspective and at the same time with the embodiment of ideas. I We recommend that museums use the analysis of inter-sectionality (race, ethnicity, gender, ..., sexual orientation and so on) to realise the idea of inclusiveness in museums.
}

In the long run this is probably a better sustainable solution than regulated parity, as the firstmentioned internalizes attention on gender (and other diversity parameters) in discourses and practices, instead of misreading symptoms as solutions.

\section{Methodological considerations}


From a methodological point of view, this article appears to be very modest. It identifies and counts the use of male and female artists' names (and "others", that is, art collectives and art groups that are not gendered by way of a name) on the museum websites for listed new acquisitions, recent exhibitions and introductory texts. This is certainly not an innovative approach, but, hopefully, it illustrates the significance of counting in these matters. However, following the theoretical inclination for queer theory, it should be noticed straight away that the implicit purpose is not to reproduce gender as a heteronormative binarity. The counting is just an easy way of putting a hegemonic discourse on display. In theory and practice, the gendered imbalance is far to compex to be reduced to figures and a simplified binary norm.

Thus, all the resulting figures are read as indices on the museum gender balance in general. Even if the museum collection is not as imbalanced as the accessible information on the museum website indicates, at least the museum communication should be altered according to gender mainstreaming as the imbalance reproduces gender stereotypes. According to this author's experience, however, there seems to be a strong correlation between information on websites and practices in the museum. When the following figures and others in an earlier version were published in a Danish context in October 2014 (Dam Christensen 2014), they were not questioned in the ensuing media debate. On the contrary, this debate instigated an official statement from the previously mentioned Academy Council, the Danish State's consultant board in matters concerning public art and architecture, funding and organization of the art world, art education, etc. This statement, entitled "Kvinder i Kunst. Mænd på Museum" ("Women in Art. Men at Museums"), urged the Danish state-owned and staterecognized art museums to cover Danish art history in all its nuances (Akademiraadet 2014). ${ }^{1}$

Moreover, it should be noted that the method counts artists, not works of art. As such, the figures are relatively small, but the counting is not skewed by, for example, large donations or acquisitions of works by a single artist which could disrupt fragile balances. The large Danish report on the acquisition policy of seven art museums (Redegфrelse for indkøbspolitikken 2005) concluded that, typically, the numbers of artists and artworks equal each other, and, in practice, the simple figures will be counter-balanced by knowledge of the practices of Danish art museums and the art scene.

The market value (or acquisition prices converted into current prices) might be another parameter which could improve the counting, but this would again demand quite an effort to implement and in fact the 2005 report gave up this aspect although it was part of the mandate. 
Thus, within the art world an abundance of other aspects generates gender inequity, probably not least practices in the art market; such a study is, however, outside the scope of this article.

So, as already indicated, all quantitative data should be handled with care, and the abovementioned method should be perceived as a humble, but also learned method, as the understanding of the counting depends on a domain-specific as well as a self-reflecting knowledge.

\section{Gendered museum communication}

\section{New acquisitions and museum websites}

The former Agency for Cultural Heritage, under auspice of the Danish Ministry of Culture, published the previously mentioned report back in 2005 . The statistics clearly showed an imbalance, heavily weighted in favor of works by male artists, in the collections of Louisiana Museum of Modern Art and the Danish National Gallery of Art, as well as five regional art museums.

As already mentioned, it is beyond the scope of this article to compete with the comprehensive statistics of the report. First and foremost, as the report consists of quantitative dataset without any explicit traces of interpretive predispositions. From a critical point of view, this simplifies and reproduces heteronormativity within an established hierarchy which, on the contrary, requires many-facetted interpretations. Of course, the status as a ministerial report might explain this lack of methodological concern to apply differentied concept and reflections.

Nevertheless, within the theoretical framework outlined in the previous, it is relevant to return to the museums in question in order to investigate changes or, rather, lack of changes in the gendered imbalance indicated by information accessible on the museum websites. In Figure 1, the acquisitions of Arken Museum of Modern Art for the period 2002-2013 are shown in terms of male and female artists (and "others", that is, as mentioned, art collectives and art groups - within the above-mentioned framework, the use of "others" might perhaps even help queering the binary norm?). Arken is a particularly interesting case as the museum has a fairly young collection (the museum opened in 1996) comprising contemporary art. In addition, the museum has initiated several events reflecting on the future of art museums as 
well as important issues within contemporary art and art museums (see, e.g. Gether et al., 2010).

Figure 1 reveals that with the exception of 2005, the only year with parity between acquisition of works by male and female artists, male artists dominate every year, in some instances even with a considerable imbalance. At a closer look, several reasons might explain this imbalance in part, for instance, a passive acquisition of donations with a majority of works by male artists, or the collection's focus on the British male artist Damien Hirst. Even if the number of male artists is reduced each year the museum has received a Damien Hirst work, the number of years with parity is not increasing. Only 2005, the year with parity, will change to a year with the smallest possible female surplus; in addition, three years are without any female acquisitions at all, but no year is without the purchase of work by male artists. Even though the figures are limited, nothing seems to indicate a significant change in the acquisition policy of the museum since 2003.

At a closer look, Arken aims at collecting art around two principles:

There are two unifying principles in the collection: one is art concerned with the existence of modern man, the other focuses on art that via new forms, materials and media explores the very definition of art.

Within contemporary art, not least the second part of this policy might seem neutral in terms of gender or even promising for a critical feminist art practice. However, as the museum director - as have other responsible directors - has on numerous occasions stated that first and foremost the acquisitions are guided by art value (see, e.g. Gether 2003), the acquisitions in the period indicate - in either a narrow-minded perspective that walks the line in counting male and female artists or a queer perspective that identifies hegemonic discourses - that male artists in general produce art of a higher quality than female artists. More specifically, male artists are better at producing art on the issues of the existence of man (!); they are also capable of exploring the very concept of art in a better way than female artists. As mentioned, this extrapolation is too one-dimensional, but, nevertheless, the extrapolation is conceivable as long as the argument of quality is not contested. 
Data on acquisition and collections from the other museums included in the 2005 report confirm the pattern from the Arken website.

On the website of Esbjerg Kunstmuseum, a list of selected (and, expectedly, the most important) acquisitions from the period 2006-2014 is accessible. Only in the year 2012 were female artists prevailing; in fact this is one of two years with purchase worth mentioning of works by female artists at all. Only in 2007, apparently a year without new acquisitions, and in 2013 parity is found (Figure 2).

The website of Sorø Kunstmuseum has no information on new acquisitions, but in the presentation of the "contemporary art" in the collection, the English text goes:

The contemporary scene is characterised by enormous diversity. The museum has sought to emphasize some of the existing themes in the collection in its acquisition policy. As an example, the landscape genre has provided a point-of-departure for acquisitions of photographic works by e.g. Per Bak Jensen and Mads Gamdrup. Minimalism and Conceptual art have prompted a special interest in contemporary artists whose work builds on analyses of formal and social structures. The contemporary collection contains works by Olafur Eliasson, Joachim Koester, Peter Land, A Kassen and Kirstine Roepstorff.

The amount of named artists is small and not necessarily representative of the ratio of male and female artists in the collection, but, nevertheless, the names must be considered artists worth mentioning. Among this small number, only one of the four mentioned artists is female (Kirstine Roepstorff); “A Kassen” is an art collective (in fact, consisting of exclusively male artists).

The same pattern is recognizable in the presentation of contemporary art, "Contemporary Art from 1990 onwards", on the website of Louisiana Museum of Modern Art. After a promising beginning the gender offensive fades:

The artwork of the 1990s is well represented by pieces by Mona Hatoum, Pipilotti Rist, Sam Taylor-Wood, Sherrie Levine, Gary Hill, Paul McCarthy, Mike Kelley and others. The 
Louisiana Collection is kept up to date with acquisitions and donations so that it also reflects the latest trends and media in contemporary art.

The most recent acquisitions range across a wide variety of media and artistic expression, with works by Jonathan Meese, Julie Mehretu, Tal R, John Armleder, Thomas Demand, Wolfgang Tillmans, Olaf Breuning, Rineke Dijsktra, Superflex, Elmgreen and Dragset, Isa Genzken, Candice Breitz, Runa Islam, Jesper Just, Aernout Mik, Doug Aitken and Bill Viola, among others.

Superflex and Elmgreen and Dragset are art collectives (however, exclusively male artists) and thus not included in the figures. This leaves nine female artists and 17 male artists in the presentation.

\section{Museum Exhibitions}

New acquisitions and inspections of gender representation in introductory remarks to collections are just two ways of examining gender equity. Another area, not included in the 2005 report, is the exhibition practices of museums. Exhibitions and catalogues, etc., are important indicators as well, as they contribute to both the artist's market value and the blueprint of promising museum acquisitions from the artist in question. These aspects further contribute to the general picture of the history of art and the expressions of the contemporary art scene as well as reflecting the so-called "aesthetic and cognitive dimensions of art", as it is inscribed in the Danish Museum Act. In other words, art museums are also agents at this level.

Again, the counting approach is effective in examining exhibition titles with either a male name or female name, although domain-specific knowledge will reveal that museum exhibitions might be small or large, short-term or long-term, and a museum can choose to spend very different resources on the exhibitions in question; these parameters are not explicit in these simple figures. Yet again, the counting points to a familiar tendency.

On the website of the art museum ARoS, the former Aarhus Art Museum and the second largest museum in Denmark, information on exhibitions in the period 2005-2013 is accessible. Once more excluding group exhibitions and exhibitions with more than one artist name in the title or subtitle, Figure 3 illustrates the gender pattern. Although two years, 2005 and 2008, show gender parity, all other years indicate an often high rate of male dominance 
in the exhibition titles; in resonance with previous figures, it is possible to find several years without female exhibitions, but no year without male exhibitions. It should be noted that the exhibition program of ARoS holds a few historically oriented exhibitions, that is, they involve periods with a specific gender imbalance; the main part, however, embraces contemporary art and living artists.

The pattern is confirmed if the approach is conducted for several of the other museums from the 2005 report. In Figure 4, for example, showing the figures from Louisiana Museum of Modern Art, three years of equity (2007, 2010 and 2013) and, not least, one year with a majority of female artists (2012) are encouraging. The representation of female artists is even strengthened this year by the exhibition Avantgardens kvinder 1920-1940 (Women of the Avant-garde 1920-1940), although, and despite all good intentions, the inverse fictive title Men of the Avant-Garde 1920-1940 probably pinpoints a hegemonic discourse that explains why the remaining eight year categories are dominated by male artists. Again, several years are without female exhibitions, but there is no year without male exhibitions. In addition, in one of the years with parity (2010) the main exhibition was Warhol after Munch and in one of the other years (2013) the main exhibition was entitled Jorn \& Pollock; these exhibitions are included as "other" in the figure.

At the National Gallery of Art in Denmark, a closer look into the exhibition program for the period 2005-2012 reveals the same shape (Figure 5). If all exhibitions are taken into account, the observation reveals strictly male dominance. As the program comprises several historically oriented exhibitions, it seems fair to include only artists who were alive at the time of exhibition. This filter leaves three years with parity (2007, 2009 and 2012), but still no female dominance, except in number of years without exhibitions.

By now it seems tedious to repeat the same picture again and again. Even though the use of filters can improve the gender balance a little, this improvement is not a matter of tilting the balance, and even in case of parity the male dominance is evident in one way or another beneath the surface. Although small progresses are grasped, the figures, more or less, document earlier studies. The overall impression shows only very slow steps towards gender equity.

\section{Male and female artists within the Danish art world}


In 2005, the Danish Minister of Culture accompanied the issue of the report Redeg $\phi$ relse for indkøbspolitikken 1983-2003 på syv danske kunstmuseer (Report on the Acquisition Policy at Seven Danish Art Museums 1983-2003, 2005) with a press release stating:

\begin{abstract}
It is part of our history that talented men were able to become professional artists, whereas talented women did not have the equivalent opportunities. However, it is going to become part of our history that equal opportunities will set foot in this domain. Not because the State commanded its museum to acquire women art. But because female artists showed matching talent when they were given the same chances for development. This report documents that we are on the right road. In the future, the potential for female artists grows according to the increasing number of female students at the art schools. (Minister of Culture 2005)
\end{abstract}

The conservative Minister predicted an approaching realization of gender equity by way of a logarithmic progression, but as the previous figures reveal there is a long journey left, and, furthermore, the significance of this progression has been overestimated before (Turner 2002). In general, more female artists than male artists are trained in art schools, but this development is not visible when looking at commercial galleries (Heartney et al. 2013, 1011). Then, might the correspondence between art students and museum acquisition be weakened by the possibility that female artists frequently give up an artistic career? This seems not to be the case in a Danish context, if the continual career is measured by way of membership of branch organizations within the art world.

The list of members of UKK (Unge Kunstnere og Kunstformidlere, an association of young artists and art communicators that since 2002 has aimed at promoting young, experimental and not necessarily established contemporary art) is accessible on the website of the association. The list shows a clear preponderance of female artists, although as the name indicates, female art communicators also surface among the 300 members; nevertheless, two thirds are female members. A related picture is repeated in the list of members of the BKF (Billedkunstnernes Forbund, the Association of Danish Visual Artists, established in 1969) where well over half of the members are female artists. Membership of BKF requires a significant amount of acknowledged artistic activity or a graduate degree from an acknowledged art school or art academy. 
According to the Danish Museum Act, the purpose of state-owned and state-approved art museums is, as mentioned, to shed light on the history of art and the expressions of the contemporary art scene as well as to reflect the previously mentioned "aesthetic and cognitive dimensions of art". For the Danish National Gallery of Art the purpose is further specified as "the obligation of shedding light on the Danish and foreign visual art, in particular from the year of 1300 and on" and in case of the Danish art in general the Gallery is obliged to acquire and keep representative collections.

From 1960 onwards the number of female artists has been growing, and gender has been explored as a relevant artistic theme. The demand for equity is of course impossible in terms of the older collections. As long as gender has been identifiable, male artists have been dominant, but moving towards modern times female artists should be more visible in the collections if gender is a mark of representation. So, if the number of female artists represented in the Danish art museums within the same period is not showing this tendency, are the museums apparently not fulfilling their legislative purpose? Actually, the question and the statistics both pinpoint implicit social structures of museums and reduce multifacetted social practices. In order to expand this complexity, a gender look at some of the other aspects of museum practices, for example leadership and educational staff, might help.

\section{Museum Staff}

\section{Directors}

In Denmark, three state-owned and 31 state-approved art museums are included in the annual report on museum statistics from the Danish Agency of Culture, Danske museer i tal. Baseret på oplysninger fra 2011 (Danish Museums in Figures according to Data from 2011, 2013), which collects statistics about the Danish museum world. An expert of the Danish art world will know that the total of 34 art museums includes differences in collection foci, small and large museums, small and large budgets, few and many annual exhibitions as well as few and many museum workers. Size matters, and so do organizational structures and collaboration relations which take place in myriad manifestations. Museums also differ in terms of regional and local political influences and representatives on museum boards, size of local and regional funding, etc. 
In recent years, regional policy has caused mergers between different types of local museums in Denmark. As a consequence, a director, manager or leader of an art museum is not necessarily the CEO of the museum. Nonetheless, if titles such as director, head of, etc., are pooled with the assumption that, no matter the specific title and position, these persons have a significant impact on the practices of the art museum in question, including acquisition, collecting and policy of exhibition and display, then the Danish state-owned and stateapproved art museums are currently headed by 13 male directors and 21 female directors (Figure 6). If the handful of regional supported art museums without official state approval is included in the statistics, the number of female directors is even higher.

At a closer look, the three largest museums (the Danish National Gallery of Art, Louisiana, and $\mathrm{ARoS}$ ) are headed by male directors today. Following the general picture, male directors will probably have higher salaries, even though this is not documented in this study. In the Danish museum world overall (including cultural history and natural history museums), the majority of museum directors are still men, even though they only make up $57 \%$ of the directorships (Burchart 2014).

A comprehensive mapping of the history of Danish art museums would affirm that the abovementioned development has been going on for a long time. In the context of this article, it serves the purpose to point to Else Kai Sass' contribution to the Festschrift of the University of Copenhagen's 500 year anniversary. In her chapter on "Museumsfolk" ("Museum staff”) no female directors are mentioned (Sass 1979). The chapter tells the story from the art historian Karl Madsen's employment as director for the National Gallery of Art in 1895 until Haarvard Rostrup's appointment as director at the state-owned Ordrupgaard Museum in 1957. However, female directors are mentioned in other places in Sass' text. The author, who was appointed in 1954 as the first female professor at the University of Aarhus, the largest Danish city next to Copenhagen, became at the same time head of the department of art at the Aarhus Museum (today, as an independent institution, named ARoS Aarhus Art Museum). In a later chapter, "Situationen omkring 1979" (“The Situation around 1979"), Sass informs her reader that a female director was appointed at Thorvaldsens Museum in Copenhagen in 1963, and that Sass herself was succeeded by another female director (1961-1969) as she moved to the University of Copenhagen and became the second female professor at that institution.

Throughout the 1970s most of the provincial art museums in Denmark began hiring university-trained art historians as heads of their museums, for example male art historians at 
the museums in Holsterbro (from 1965) and Silkeborg (today Museum Jorn, 1973). Simultaneously, female art historians were appointed as heads of museums, for example J.F. Willumsens Museum (1977), Kastrupgårdsamlingen (1977), Nordjyllands Kunstmuseum (today Kunsten Museum of Modern Art Aalborg, 1979) and Faaborg Kunstmuseum (1981). In connection with the state-owned museums other female directors surfaced, for example the director of the Hirschsprung Collection 1978-1985 and thereafter Ordupgaard Museum 1985-1995, where the director was succeeded by another female director. At the Hirschsprung Collection the director in question was also followed by a female director. It is also worth mentioning that although male directors have dominated the Danish National Gallery of Art, a female director was head of this museum for the period of 1994-2007.

The female majority of directors at Danish art museums follows a tendency in Western art museums, although the almost 2:1 ratio seems rather high (see, e.g. Schwarzer 2007 and Turner 2002). Female directors have for some times outnumbered male directors at Danish art museums, but this statistic is no cure against gender inequity in acquisition policies. In comparison with international experience this would also have been a surprise. In "Women in the Temple: Gender and Leadership in Museums", Schwarzer 2010: 25) quotes a museum worker:

Whatever gender parity has been achieved institutionally, it has not been achieved in exhibitions and galleries. Even though museums have acquired more artworks by women since the mid-1970s, there is a discrepancy between what's collected and what's shown. The art historical canon remains partriachal; directors may challenge the rules of the workplace but not in their choices of exhibition themes. $(2010,25)$

Historically speaking, the visibility of female directors and leaders is well known, although the history is not without repercussions. As an early example, Schwarzer mentions Juliana Force, appointed as director for Whitney Museum of American Art in 1929. Schwarzer goes on: "chances are high, that if you work in a museum that existed in the 1910s and 1920s, women played strong internal leadership roles at your institution" $(2010,19)$. However, in the decades following the Second World War, men were appointed to fixed positions, whereas women apparently primarily entered the museum world on an unpaid basis, at least until 1970 
when women regained significance as leaders $(2010,19)$. Nevertheless, a gender barrier remains, according to Schwarzer:

Women compose about 63 percent of all professional and senior-level staff in the field, twice the average representation of men. ... Despite women's presence, men dominate museums in two critical areas: power and money. (2010)

A prevalent explanation to gender imbalances is often the idea of "the old boys' network". However, as the previous figures and discussions indicate, this is, again, a simplistic assumption that, alongside the affirmation of gender as a category of differentiation, might overshadow other explanations, which, in the present case, involve other facets of museum practices, e.g. in regard to staff responsible for learning and education.

\section{Educators}

Closing in on the staff in museums responsible for learning and education, a troubling picture is revealed. The following rhetorical question indicates the problems in advance: is the education staff dominated by male or female employees? Probably, most people intuitively reply "female", which also seems to be the correct answer. Without documentation for newer figures, Katy Deepwell hits at this reply in her article "Feminist Curatorial Strategies and Practices since the 1970s":

Curation in museums and galleries of contemporary art is a female-dominated profession, a fact which often leads the woman curator to be regarded as a 'keeper of culture' (rather than producer) ... As in many other professions, there is an asymmetrical pyramid in the operation in museum curation with regard to gender. Many of the positions at the top of the pyramid - in the hierarchy of national museums - are still held by men. $(2006,65)$

Nina Simon recaps a related understanding in a much commented on blog post entitled "Is the Gender Imbalance in the Arts a problem?” (2013): 
Even the museums I worked in with a fairly equivalent gender balance were completely out-ofwhack when you looked at departments. Exhibits, technology, security, and senior management were majority male. Education and programs were female central.

A tentative survey of staff responsible for education at Danish art museums documents these apprehensions. Although the staff cannot be identified in the same way as the director or leader on the museums' websites, it is possible to identify positions such as head of learning department, head of education, head of education and communication, communication curator (children and adolescents), etc. The resulting gender balance is without doubt: this is an exclusively female domain (see Figure 7). Probably, the gender imbalance is reinforced at lower levels within the educational activities and departments.

\section{Discussion}

Whereas the imbalance of female/male directors did not look disturbing, might it be another case with regards to educational activities? In the name of equal treatment, the heavy imbalance of female employees ought to be considered a problem, although explanations might be easy to find. Lower salaries, lower positions in organizational hierarchies, flexible working conditions, non-research positions, non-fixed positions, etc., could probably explain the disproportion in part. Nevertheless, it is tempting to suggest that the high numbers of female educators and works of male artists in the collections and exhibitions echo a mythological relationship between the artist and his muse, that is, the creator and the more or less silent hostess. The traditional art historical discourses are saturated with echoes of this asymmetrical relationship between an active male agent and a passive female agent.

Even though this resemblance between myth and statistics only surfaces by coincidence, it exposes a point which sometimes needs to be repeated. Gender-engaged art museum directors, art historians, artists, critics, etc., might individually fight for equal treatment, but in a general sense their agency is subsumed by - in a pell-mell - trajectories, structures, discourses and practices which apparently uphold or reflect gender-reproducing mechanisms. These mechanisms have been the object of critical studies and investigations for several decades without significant alterations in the daily life of the art world. 
In order to renew critical reflections, this article will lastly indicate a point which is only seldom contested in the discourses on art and gender issues: the idea of art value. Although this concept is higly debated, it is almost naturalized as a blind spot in the hegemonic discourses of art museums. It seems to possess a magic aura as a wonder not to be challenged because of the positive connotations of art and museums. Evidently, responsible art museums acquire art objects of high value, not secondary art, fake art, bad art, junk art, etc. In addition, most female artists want their works to be bought by the art museum because of quality and not gender in order not to be accused of making minor art.

It is, however, difficult to find consensus among agents on definitions of art and the value of art. Without summing up the many-facetted history of definitions of art and art value, it is reasonable to assume that the notions of art and quality with regard to art museums are founded on disciplinary knowledge and personal preferences. Those preferences are, however, only "personal” by way of a disciplinary socialization as well as, for instance, Habitus according to the French sociologist, Pierre Bourdieu. Within his Marxist-inspired theoretical framework cultivated taste is not a natural gift, but a socially internalized disposition (Bourdieu and Darbel 1991). Thus, even if identity is more complex than class distinctions and social position might determine, it seems sound to assume that notions, perceptions or senses of bad and good quality arise in an invisible area of tension between "personal" taste and disciplinary socialization. What if the gender-reproducing mechanisms also ascend from this area of darkness and can go on doing this as long as the art museum managements are not forced to present adequately reflected arguments on their acquisition policy?

Without these more acute arguments, the gender inequity in acquisitions and exhibitions might seem to be derived from the clear fact that male artists in general produce better art than their female colleagues; at least, narrow-minded statistics strongly support this proposition. However, whether an artist is male or female is very seldom recognizable from a single work of art, although certain themes as well as artistic media might seem to appeal to either male or female artists and, thus, can be recognized as such. If, for example, performance art and video seem to attract more female artists than male artists, it is a disadvantage to parity, because art museums are keener to acquire works of traditional media (Heartney et al. 2013). Neither quantitative data on gender in art musuems, nor a hegemonic discourse on art value can be divided from domain-specific and self-critical knowledge. 
The absence of reflected arguments is further exposed by way of the condition that whether a work of art is of sufficiently high quality or not (if such a quality ever can be defined) often does not really matter until the responsible director, roughly speaking, is sitting in front of the work in question. Before this final act, the director, the museum board, the relevant curators, etc., have made a long series of strategic decisions according to the museum mission, budgets, concentration in the existing collection and many other aspects. Thus, factors such as expenses, regionalism, nationality, art historical periods, isms, motifs, media, genres, etc., function as filters that, in advance, impact decisions on which art works to acquire for the particular museum. If appropriate agents accept that they take part in constructing reality, one might ask why gender shouldn't be implemented as such a filter? In other words, the concept of quality is easily relativized according to a series of well-known parameters, so why not gender? In the line of this argument, it is a repressive logic if female and male artists do not want their works to be acquired by an art museum because of biological sex. Instead of subjugation to the museal "god trick", where the idea of art value is performed from a privileged point of view without body, both museums and artists have agens, that is, are embodied in the construction of reality (cf Donna Haraway's discussion of scientific objectivity vs situated knowledge, 1988).

Again, it must be pointed out that in spite of all previous statistics, this article is not acclaiming parity between male and female artists in museum collections. Gender parity is not a goal in itself. A narrow focus on gender parity might even overshadow critical changes and possibilities as it pertains to mechanisms that have already been marginalizing female artists once. This argument could include male artists who are not subject to or who do not fit into these mechanisms as well, but we do not know; in fact, this is an evident example of an excluded position within the binary categories of male and female artists.

Unstable notions of femininity and masculinity are linked to cultures, time and space, etc., but are also constantly negotiated in cultures, time and space as well. As mentioned, already the dichotomy male/female addresses a simplification which stabilizes binarity as a future premise to be achieved whereas, in fact, the imbalanced figures of male and female artists should rather be considered a symptom of something that need to be investigated. This could be the case, for example, if the acquisition or exhibition ratio between male and female artists doesn't correspond to other gender balances in terms of, for example, membership of artists' associations, graduated artists, the awarding of artistic merits, and so on. The point is that the gender question in art museums has no easy answers. 
This is further accentuated by the fact that gender-reproducing mechanisms might be situated in other places that can impact the museum acquisitions, for example, the commercial gallery world, art journals, private donations, etc. Thus, if Danish art museums are supposed to shed light on the history of art and the expressions of the contemporary art scene as well as to reflect the so-called "aesthetic and cognitive dimensions of art" and, as in the case of the Danish National Gallery, keep representative collections, the question remains: is the gender imbalance in art museums just mirroring aspects of the contemporary art scene?

This doesn't rule out the possibilities of strengthening the attention on gender mainstreaming in the art museums, at least not in a Danish context with regulated state-owned museums and state-approved museums. The aforementioned Agency for Culture conducts regular assessments of the museums, among other things, in order to ensure that they comply with a number of requirements in the Danish Museum Act. These assessments could easily incorporate figures on gender, for example in terms of acquisitions, exhibitions, educational activities and so on, as a way to facilitate some of the approved recommendations addressing gender mainstreaming from Resolution 4 at ICOM's 28th General Assembly (2013).

From a methodological point of view, the simple counting, which can be handled by the museums themselves without need of a strong regulation by governmental agencies, might with a certain amount of domain-specific and self-reflective knowledge - easily map diversity issues within the domain of art museums, if one actually wants to map them. Again, however, parity should not be a goal or solution in itself, but rather considered as a symptom indicating - not proving - lack of diversity.

\section{References}

Akademiraadet. 2014. “Kvinder i kunst. Mænd på museum.” Released December 16, 2014. http://www.akademiraadet.dk/assets/files/Raadet/Udtagelser/2014/Kvinder_i_kunst_maend_p aa_museum.pdf.

Arken Museum of Modern Art. 2015. Accessed June 18, 2015. http://uk.arken.dk/om-arken$2 /$.

BKF. 2015. Billedkunstnernes Forbund. Accessed September 9, 2013. http://www.bkf.dk/. 
Bourdieu, Pierre and Alain Darbel (with Dominique Schnapper). 1991. The Love of Art: European Art Museums and Their Public. London: Polity Press

Burchart, Louise E. 2014. "Gender Perspectives in Museums.” In Museum: Knowledge, Democracy, Transformation, edited by Ida B. Lundgaard and Jacob T. Jensen, 166-175. Copenhagen: Kulturstyrelsen. Accessed June 18, 2015. http://www.kulturstyrelsen.dk/fileadmin/publikationer/Kulturarv/Museums_Knovledge_dem ocracy_transformation.pdf.

Crowley, Kevin. 2000. "Parent Explanations during Museum Visits: Gender Differences in how Children hear Informal Science.” Visitor Studies Today 3(3): 21-28.

Crowley, Kevin, Maureen A. Callanan, Harriet R. Tenenbaum, and Elizabeth Allen. 2001. "Parents explain more often to Boys than to Girls during Shared Scientific Thinking." Psychological Science 12(3): 258-261.

Cruz, Emily. 2014. “Gender and the Art Institute: Still A Man's World.” Editorial. CUSP Magazine, September 29. Accessed June 8, 2015. http://cuspmagazine.com/gender-and-theart-institute/.

Dam Christensen, Hans. 2014. "Med kønnet på museum. Skævhed i museernes indkøbspolitik.” In 100 års фjeblikke. Kvindelige Kunstneres Samfund, edited by Charlotte Glahn and Nina Marie Poulsen, 258-377. Copenhagen: Forlaget Saxo.

Danish Agency of Culture. 2013. Danske museer i tal. Baseret på oplysninger fra 2011. Copenhagen: Kulturstyrelsen.

Deepwell, Katy. 2006. "Feminist Curatorial Strategies and Practices since the 1970s." In New Museum Theory and Practice: An Introduction, edited by Janet Marstine, 65-84. Oxford: Blackwell Publishing.

Degele, Nina. 2008. “1. Gender/Queer Studies: Wozu das Buch? ”. In Gender/Queer Studies. Eine Einführung, edited by Nina Degele, 9-23. Paderborn: Wilhelm Fink

Dimitrakaki, Angela, and Lara Perry, eds. 2013. Politics in a Glass Case: Feminism, Exhibition Cultures and Curatorial Transgressions. Liverpool: Liverpool University Press.

Esbjerg Kunstmuseum. 2015. Accessed June 23, 2015. http://www.eskum.dk. 
Gan, Anne Marie, Zannie Giraud Voss, Lisa Philips, Christine Anagnos, and Alison D. Wade. 2014. The Gender Gap in Art Museum Directorships. Association of Art Museum Directors.

Gether, Christian. 2003. "Referat af Chritian Gethers konferenceindlæg." In $F \phi r$ usynligheden - Om ligestilling i kunstverdenen, edited by Høyer Hansen, Lone, Dorte Jelstrup, Kirsten Justesen, Anita Jørgensen, Malene Landgren, Lisa Rosenmeier, Åsa Sonjasdottor, Elisabeth Toubro, and Mai Misfeldt, 50-53. Copenhagen: Gyldendal.

Gether, Christian, Stine Høholt, Marie Laurberg, Britta Tøndborg, Christina Papsøe Weber, Lise Sattrup, and Marie Bramsen. 2010. Fremtidens Museum. Ishøj: Arken Museum for Moderne Kunst.

Haraway, Donna. 1988. "Situated Knowledge: The Science Question in Feminism and the Privilege of Partial Perspective.” Feminist Studies 14(3): 575-599.

Heartney, Eleanor, Helaine Posner, Nancy Princenthal, and Sue Scott. 2013. The Reckoning: Women Artists of the New Millennium. Munich, London and New York: Prestel.

Hein, Hilda. 2007. "Redressing the Museum in Feminist Theory." Museum Management and Curatorship 22(1): 29-42.

ICOM. 2013. Resolution adopted by ICOM's General Assembly, Rio de Janeiro, August 2013. Accessed June 8, 2015. http://icom.museum/the-governance/generalassembly/resolutions-adopted-by-icoms-general-assemblies-1946-to-date/rio-de-janeiro$2013 /$.

Jackson, Stevi. 2006. “Gender, Sexuality and Heterosexuality. The Complexity (and Limits) of Heteronormativity. " Feminist Theory 7(1): 105-121.

Latour, Bruno. 2010. “Tarde's Idea of Quantification.” In The Social After Gabriel Tarde: Debates and Assessments, edited by Candea, Mattei, 145-162. London: Routledge Louisiana Museum of Modern Art. 2014. Accessed September 9, 2014. http://www.louisiana.dk/dk/Menu/Samlingen/Om+samlingen/Samlingens+udvikling. Machin, Rebecca. 2008. "Gender Representation in the Natural History Galleries at the Manchester Museum." Museum and Society 6(1): 54-67. 
Mair, Michael, Christian Greiffenhagen, and W.W. Sharrock. 2015. "Statistical Practice: Putting Society on Display." Theory, Culture \& Society preprint, January 2015. DOI: 10.1177/0263276414559058: 1-27.

Minister of Culture, Denmark. 2005. "Mænd dominerer kunstmuseerne.” (press release). Accessed October 25, 2013. http://www.kulturstyrelsen.dk/nyheder/nyhedsarkiv-kulturarvsstyrelsen/singlevisning/artikel/maend_dominerer_kunstmuseerne/.

Morrissey, Kris. 2008. “Editor’s Note: Language as Context: Can I say 'Queer’ if I'm not? Thinking differently requires speaking differently.” Museums \& Social Issues 3(1): 3-4.

Museum Act, Denmark. 2014. Accessed June 23, 2015.

https://www.retsinformation.dk/forms/r0710.aspx?id=162504.

Nochlin, Linda. 1971. "Why Have There Been No Great Women Artists?” Artnews 69: 2239.

Redegфrelse for indkфbspolitikken 1983-2003 på syv danske kunstmuseer (2005) [Report on the Acquisition Policy at Seven Danish Art Museums 1983-2003]. Copenhagen: Agency for Cultural Heritage.

Sass, Else Kai. 1979. “Kunsthistorie.” In Kobenhavns Universitet 1479-1979 Vol. IX, edited by Povl J. Jensen, 199-343. Copenhagen: University of Copenhagen..

Sorø Kunstmuseum. 2015. Accessed May 20, 2015.

http://www.sorokunstmuseum.dk/en/collection/350-years-of-danish-art/contemporary-art.

Schwarzer, Marjorie. 2010. "Women in the Temple: Gender and Leaderships in Museums." In Gender, Sexuality, and Museums (A Routledge Reader), edited by Amy K. Levin, 16-27. New York: Routledge.

Simon, Nina. 2013. "Is the Gender Imbalance in the Arts a problem?" http://museumtwo.blogspot.dk/2012/09/open-thread-is-gender-imbalance-in-arts.html.

Steorn, Patrik. 2010. "Queer in the Museum: Methodological Reflections on doing Queer in Museum Collections." Lambda Nordica 3-4: 119-142. 
Sundberg, Martin. 2011. "Innanför och Utanför Tullarna: Moderna Museet.” In

Representation och regionalitet. Genusstrukturer i fyre svenske konstmuseisamlingar, edited by Anna Tellgren and Jeff Werner, 26-53. Stockholm: Statens Kulturråd.

Tellgren, Anna, and Jeff Werner, eds. 2011. Representation och regionalitet. Genusstrukturer i fyre svenske konstmuseisamlingar. Stockholm: Statens Kulturråd.

Turner, Victoria. 2002. “The Factors Affecting Women's Success in Museum Careers: A Discussion of the Reasons More Women Do Not Reach the Top, and of Strategies to Promote their Future Success.” Journal of Conservation and Museum Studies 8: 1-16.

UKK. 2013. Unge Kunstnere og Kunstformidlere. Accessed September 20, 2013. http://ukk.dk/?q=indhold/om-ukk/medlemmer.

\footnotetext{
${ }^{1}$ In Denmark, the State owns seven museums, and 98 are approved to receive state subsidies. The Danish Agency for Culture supervises all state-subsidized (approved) museums and most of the state-owned museums. A state-approved museum can be owned by one or several local authorities or by an association whose objective is to run the museum, or it can be an independent institution. State-owned and approved museums are subject to the Danish Museum Act and must comply with a number of requirements as stated in the Act. The National Gallery of Art is a state-owned museum, where as Ordrupgaard and Hirschsprung's collection, the other two art museums with status as state-owned museums, achieved their status due to specific historical circumstances.
} 